\title{
4.2 Modern concept of controlling in anti-crisis management of the enterprise
}

Контролінг в нинішніх умовах антикризовості можна розглядати як оволодіння й управління економічною діяльністю на підприємстві на базі сучасного інноваційного інструментарію. Еволюційно контроллінг впроваджувався функціонально через окремі види діяльності й структурні підрозділи (постачання, збут, фінанси, виробництво....). Це не приводило до значних результатів, оскільки інші фактори залишалися без уваги й вони не приймали участі в підтримці того чи іншого контроллінгового заходу. Наприклад, при застосуванні контролінгу в постачанні можна знизити витрати на закупку різних сировинних компонентів. В той же час при їх використанні у виробничому процесі внаслідок появи великої кількості бракованих деталей може не бути збільшення кількості готових виробів, в результаті чого не будемо мати того ефекту при умові, що контролінг здійснюється на протязі всієї технологічної мережі (постачання, виробництво, збут). Аналогічна ситуація може мати місце й при відсутності контроллінгу в інших підрозділах підприємства (фінансовий, кадровий, маркетинговий, логістичний), де не проводяться контролінгові дії з метою зниження витрат на обслуговування основного виробничого процесу.

Розвиток контролінгу відбувається за наростанням його ролі та значущості в менеджменті при збереженні основної мети - орієнтація управління на досягнення цілей підприємства. При цьому уточняються його об'єкт та засоби, завдання та функції. Фалько С.Г. досліджував етапи становлення та розвитку контролінгу в практичній діяльності підприємства і він виділяє такі концепції: 1) Реєстраційна (виникла на початку ст. й активно розвивалася ло 30 -х років). 2) Обліково-аналітична (почала формуватися під час економічної кризи 30 -х років). 3) Концепція внутрішньо-фірмової інтеграції (формувалася в 70-ті роки одночасно $з$ розвитком інтегрованих автоматизованих систем планування виробництва). 4)Координаційно-навігаційна концепція (активн становлення розпочалося наприкфнці 80 -х - на початку 90-х років). 5).Концепція стратегічної 
навігації (лише формується і широкого застосування ще не набула) постановка й розвязання завдань інформаціонно-аналітичної підтримки стратегічного менеджменту. 6). Концепція контролінгу, спрямована на узгодження інтересів зацікавлених осіб у рамках реалізації принципів корпоративного управління(Corporate Governance) [239].

Аналізуючи зарубіжні та вітчизняні науково-практичні джерела, можна стверджувати, що найпоширенішими сьогодні є три концепції контролінгу, які загалом включають характеристики окреслених вище шести концепцій.

1. Контролінг з орієнтацією на функцію контроля. Особливість цієї концепції заключається в тому, що проведення перманентного контролю за відхиленнями фактичних даних від планових має на меті своєчасне реагування та розробку оперативних заходів щодо ліквідації виникаючих проблем. Такий контроль не має на меті знайти виновного та наказати його а спільно й оперативно знайти рішення по відновленню процесу виготовлення продукції. 2. Контролінг як інформаційна функція. Вона представляє систему інформаційного забезпечення управлінських рішень через планування, контроль, аналіз та розроблення альтернативних заходів. Створення в цьому контексті служби контролінгу на підприємстві необхідно насамперед для зменшення інформаційної асиметрії між менеджментом та підрозділами управління фінансами. 3. Контролінг як функція координації. Він зв’язує всі управлінські функції воєдино, активізує їх діяльність та фокусується на координацію підсистем менеджменту.

За уявленнями американських дослідників контролінг - це рівноправна серед інших управлінська функція. Класичними функціями менеджменту $є$ планування, організація, управління кадрами, керівництво та контролінг. Відповідно до них сукупність управлінських завдань та дій розподіляється за окремими субобластями. $\mathrm{y}$ межах такого аналітичного розподілу має проводитися чітке розмежування між різними управлінськими функціями. Оскільки в функції координації контролінг зв’язує й активізує всі управлінські функції й фокусується на координацію менеджерських підсистем, можна лишній раз стверджувати на його опосередковану всеохоплюючу функцію. 
На нашу думку, у еволюційно сформованих концепціях контроллінгу не враховані необхідні аспекти для сучасного ефективного управління: 1) функціонування підприємств в умовах перманентних ризиків і невизначеності; 2) всеохоплюючий характер контроллінгу, направлений на одержання максимального позитивного результату або ефекту; 3) необхідність переходу до постійного антикризового управління замість класичного менеджменту; 4) впровадження вартісно-орієнтованого підходу в сучасному менеджменті компанії; 5) формування концепції контроллінгу для кожного підприємства 3 урахуванням його специфічних умов; 6) необхідність перманентності контроллінгового управління; 7) поглиблений акцент на контроллінгове стратегічне управління; 8) необхідність запозичення зарубіжного, зокрема, німецького досвіду застосування контроллінгу в управлінській діяльності.

Зведення різних концепцій в єдину систему повинно базуватися 3 урахуванням ситуації в часі. Усі попередні концепції відповідали викликам відповідного конкретного періоду. Вони залишаються можливими для практичного використання в нинішніх умовах на будь-якому підприємстві 3 урахуванням його конкретних особливостей. Що стосується сьогодення, то воно призводить до необхідності враховувати нові виклики й вносити значні коригування в концепцію контролінгу. Основними чинниками для такого коригування є: 1) постійна нестабільність в зовнішньому середовищі; 2) функціонування підприємств в умовах невизначеності; 3) не прогнозовані кризові явища, які можуть появитися в будь-який період на підприємстві; 4) глобалізація економічних відносин; 5) фрагментарність інноваційного, контроллінгового, антикризового й вартісно-орієнтованого управління на підприємствах. Слід відзначити, що еволюція понятійного апарату й концепцій контролінгу зовсім не віддзеркалюють ці чинники як термінологічно так i контентно. Вони з'явилися в останні $2-3$ роки. Приведені чинники прямо або опосередковано пов’язані антикризовим менеджментом. 
Слід відзначити, що сьогодні поняття антикризового управління досить багатозначне й різноконтентне. Одні науковці під ним розуміють управління компанією тільки в умовах загальної (в межах країни або міжнародної) кризи економіки, для інших це управління підприємством, що потрапило в кризову ситуацію внаслідок незадовільного менеджменту. Також є думки, що це є управління на порозі або в період банкрутства. Це не дивно тому, що аналізуються думки різних періодів. Річ в тому що в економічних явищах немає стійких термінів. 3 часом вони змінюються під впливом різних наукових, технічних, економічних, соціальних, організаційних та управлінських факторів. В останні роки появилися нові форми управління, організаційні методи, міждисциплінарні курси. В більшості наукових публікацій, особливо дисертаційного напрямку розглядаються авторські підходи щодо інтерпретації багатьох економічних термінів. В найбільшій мірі необхідність актуалізації змісту економічних термінів обумовлюється турбулентністю зовнішнього середовища та функціонуванням економічних систем в умовах невизначеності та ризиків. Відносно астрономічного часу акцент повсюди в управлінській діяльності змістився на прогнозування розвитку тієї чи іншої підвладної системи [240, с. 46 ]. Сьогоднішні події в світі призвели до необхідності перегляду всіх наукових постулатів і трактовки економічних термінів.

Узагальнюючи наукові підходи до сутності сьогоднішнього антикризового управління, можна констатувати наступне: 1) не звертається значна увага на вплив зовнішніх факторів на діяльність підприємств; 2) в дефініціях не віддзеркалюються стадії життєвого циклу підприємства і його продукції; 3) не враховуються нормативно-правові документи; 4) відсутній акцент на превентивне управління; 5) немає інформації щодо визначення й прогнозування банкрутства; 6) значна частина визначень обмежується внутрішніми аспектами антикризового управління; 7) не приймається до уваги оцінка ефективності антикризового менеджменту компанії; 8) практично за межами визначень знаходяться інноваційні управлінські технології вартісно-орієнтованого 
управління й контролінгу; 9) у визначеннях домінує переважно фінансовий аспект [241, с.176-177]. Еволюційний аналіз наукових джерел по антикризовому управлінню дозволяє зробити наступні висновки [241, с.176 ]. .

1. Можливе виділення 2 умовних етапів в судженнях про термін антикризового управління. Приблизно до 2012 року визначення цієї дефініції в основному стосувалися періоду кризи й виходу з неї і лише в деяких публікаціях з'являлися фрагменти визначень про необхідність урахування аспектів передкризового стану та вдосконалення моделей аналізу фінансової стійкості підприємства та небезпеки банкрутства. Після 2012 року акцент почав переміщуватися в бік розширеного бачення антикризового управління 3 наповненням цього терміну такими аспектами як превентивне антикризове управління, вартісно-орієнтоване управління, контроллінгове антикризове управління. 2. Наповнення контентів антикризового управління стратегічною орієнтацією та необхідністю вдосконалення інформаційно-методичної, зокрема, стратегічної бази такого управління. 3. Приділення значної уваги контроллінгу як управлінській функції й інструментарію антикризового управління. 4 . Прийняття до уваги екзогенних факторів, які відображають процес гармонізації інтересів і поведінки всіх учасників створення, виготовлення й реалізації продукції компанії. 5. Пошук нових інноваційних методів для оцінки фінансового стану підприємства 3 урахуванням інтернаціональних, національних, галузевих і статусних особливостей [3, с 176 ].

Таким чином, дослідження сутності поняття «антикризове управління» в наукових працях дозволяє констатувати, що воно в нинішніх умовах потребує актуалізації, конкретизації, фокусування, розмежування та установлення взаємозв'язку між його складовими . 3 урахуванням проаналізованих наукових джерел та авторських суджень можна представити наше сьогоднішнє бачення антикризового управління підприємством, як: “перманентне стеження за ознаками можливої появи тенденції наближення до кризової ситуації, формування й реалізація відповідних оперативних та стратегічних управлінських рішень в умовах ризику й невизначеності, ресурсних та часових 
обмежень в окремі періоди, фінансових та інтелектуальних витрат на відновлення та підтримку життєздатності підприємства й недопущення ліквідації його як суб’єкта господарювання” [ 241, с. 176-177 ].

Запропоноване визначення має наступні особливості: 1) враховує не тільки внутрішні складові, але й зовнішні чинники впливу на діяльність підприємства, які можуть бути враховані за допомогою зовнішнього моніторингу; 2) включає фінансові і не фінансові показники діяльності підприємства; 3) уможливлює в значній мірі адаптацію та гнучкість підприємства й здатність його до перманентного реагування на слабкі сигнали мінливого зовнішнього середовища; 4) дозволяє оцінювати ефективність менеджменту; 5) включає інтелектуальний капітал в процес антикризового управління [241, с. 177].

Слід акцентувати увагу на тому, що таке визначення антикризового управління пропонується для підприємств 3 відсутністю контроллінгу й вартісно-орієнтованого управління. Якщо компанія в своїй діяльності застосовує вартісний підхід і контроллінг, але має ще ознаки класичного менеджменту, тоді це визначення антикризового управління має включати елементи антикризових заходів. Лише при наявності тотального безперервного антикризового менеджменту використанням контроллінгу й вартісно-орієнтованого управління можна запропонувати авторське бачення цього терміну таким чином: «Контроллінгове антикризове вартісно-орієнтоване управління - це сучасне перманентне всеохоплююче управління в умовах невизначеності й ризиків 3 використанням вартісних показників для динамічного оцінювання приросту вартості підприємства, конкурентоспроможності його продукції й ефективності інноваційного менеджменту»[ 242, с.632].

Враховуючи авторське визначення й різні погляди науковців на сутність та завдання антикризового управління, можна констатувати, що нинішня всеохоплююча не визначена ситуація в світі дозволяє переконатися лишній раз, що термін антикризового управління має повністю замінити поняття простого або класичного управління. Від епізодичного або періодичного антикризового управління необхідно перейти до постійного й превентивного антикризового 
управління [241,с.177]. Складовими його концепції являються вартісноорієнтований підхід, антикризовий контролінг і превентивний менеджмент. В цьому аспекті ми розділяємо думку науковців $[243,244]$ стосовно сучасних вимог до структури та задач управління підприємством або установою, які вважають конче необхідним надання управлінню будь-яким підприємством ознак перманентної антикризовості. 3 урахуванням цих ознак в табл.1 представлена концепція контроллінгового антикризового вартісноорієнтованого управління компанією, яка загалом віддзеркалює необхідність такого управління в умовах невизначеності й непередбачуваності появи кризових явищ [245 ].

Таблица 1

Концепція контроллінгу в антикризовому управлінні підприємством

\begin{tabular}{|c|c|}
\hline $\begin{array}{l}\text { Назва концепції й } \\
\text { період ії становлення }\end{array}$ & Визначення й загальна характеристика концепції \\
\hline \begin{tabular}{|l} 
Концепція \\
контроллінгового \\
антикризового \\
вартісно- \\
орієнтованого \\
управління, 2020p.- по \\
теперішній час
\end{tabular} & $\begin{array}{l}\text { Контроллінг - функція управління, яка направлена на досягнення } \\
\text { запланованих поточних та прогнозних показників й забезпечення } \\
\text { довгострокового функціонування фірми в заданих інтервалах } \\
\text { траєкторії їі розвитку а також своєчасне виявлення та ліквідацію } \\
\text { «вузьких місць» в її діяльності. } \\
\text { Контроллінгове антикризове вартісно-орієнтоване управління - це } \\
\text { сучасне перманентне всеохоплююче управління в умовах } \\
\text { невизначеності й ризиків з використанням вартісних показників для } \\
\text { динамічного оцінювання приросту вартості підпиємства, } \\
\text { конкурентоспроможності його продукції й ефективності } \\
\text { менеджменту». } \\
\text { Контроллер виконує роль консультанта або тренера, який допомагає } \\
\text { управлінцям перейти на контроллінговий самоменеджмент. Він } \\
\text { проводить тренінги серед працівників компанії щодо підвищення } \\
\text { знань, необхідних для виконання функцій у контроллінговому } \\
\text { середовищі. Окремі контроллери можуть бути як топ-менеджерами, } \\
\text { так і радниками у топ-менеджерів. }\end{array}$ \\
\hline
\end{tabular}

Розроблено з урахуванням [ 246,247 ].

Впровадження такої концепції потребує певної підготовки керівних i виконавчих ланок. Усі або більшість профільних менеджерів різних рівні в певній мірі володіти контроллінговою термінологією, методами й інструментарієм, щоб мати можливість раціональніше використовувати 
інформаційний масив результуючих індикаторів й більш кваліфіковано підходити до прийняття управлінських рішень на основі контроллінгової інформації. Одночасно це дозволить цілеспрямовано й ефективно здійснювати вплив на виконавців таких рішень і придержуватися також контроллінгових підходів у своїй діяльності. В такому разі самоменеджмент буде охоплювати всю низку керівників і виконавців того чи іншого управлінського рішення.

Сьогодення свідчить, що в умовах непередбачуваного, мінливого та конкурентного оточення традиційні способи інформаційної підтримки прийняття управлінських рішень також стають не ефективними й перешкоджають досягненню заданих цілей. В нинішніх умовах недостатнім $€$ аналіз вартості підприємства лише на базі минулої та поточної інформації. Необхідно прогнозувати також сценарій майбутньої ситуації з метою вибору ефективних шляхів зростання вартості компанії. Маючи таку інформацію, антикризове управління може спрямувати свої дії на створення вартості, де основним пріоритетом буде майбутній фінансовий результат та сподівання інвесторів. Глобалізація економічних відносин, значне посилення конкуренції, стрімкий розвиток фінансового та фондового ринків обумовили необхідність змінити підхід до управління підприємством. Виникла потреба у формуванні підходу, здатному забезпечити зростання вартості підприємства у довгостроковій перспективі та збалансувати інтереси акціонерів та менеджерів. Внаслідок цих обставин виникла необхідність у підприємств впроваджувати концепцію 3 назвою: вартісно-орієнтованого управління - VBM (Value-based management).

Впровадження вартісно-орієнтованого управління на вітчизняних підприємствах залежить від особливостей їх функціонування [248]: 1) Недосконалість ринку капіталу України і майже повна відсутність будь-якої торгівлі акціями [249, с. 138]. 2) Порушення права акціонерів на участь у розподілі прибутків; 3) розмивання власності акціонерів через додатковий випуск акцій товариства; 4) виведення активів із власності АТ, що знецінює акціонерну власність; 5) непроведення загальних зборів товариства або 
проведення з порушеннями; 6) відсутність реального нагляду за діяльністю АТ 3 боку спостережних рад ; 7) Високий рівень тінізації економіки України, яка негативно впливає на інвестиційну складову розвитку акціонерних товариств. [ 249, c.138]; 8) чіткий тренд щодо отримання конкурентних переваг і доходів не економічними методами.

Основними проблемами впровадження управління вартістю в діяльність вітчизняних підприємств $€$ наступні: 1) традиції управління фінансами на основі таких класичних фінансових показників, як прибуток і рентабельність; 2) погляд на вартість підприємства як на суму вартості активів або як на поточну необхідність активного використання окрім даних бухгалтерського обліку даних ринку капіталу для виявлення економічного прибутку і вартості; 3) відсутність стилю мислення, сфокусованого на економічний прибуток й інвестиційну вартість підприємства [ 250, с. 121].

Впровадження вартісно-орієнтованого управління означає зосередженість всіх ключових підрозділів та процесів на створенні вартості. Загальна стратегія вартісно-орієнтованого управління повинна охоплювати стратегічне планування, розміщення капіталу, оперативне бюджетування, оцінку результативності, систему мотивації, внутрішню й зовнішню комунікацію. Це єдина система, що складається 3 набору як оперативних, так і стратегічних інструментів, що використовуються для сприяння прийняттю бізнес-рішень, які мають забезпечувати постійне зростання вартості компанії [248]. Проблема впровадження вартісно-орієнтованого управління $\epsilon$ актуальною також для неакціонерних компаній різних розмірів, оскільки забезпечує конкурентоспроможну дохідність для їх власників.

Концепція вартісно-орієнтованого управління розкриває широкі можливості для підвищення ефективності антикризового менеджменту на підприємстві. Велика кількість показників вартості (RE -чистий залишковий прибуток, EPекономічний прибуток, EVA-економічна додана вартість, CVA - грошова додана грошова вартість, SVA- акціонерна додана вартість - MVA - ринкова додана вартість , SV- стратегічна вартість, TSR - загальна віддача акціонерам) [ 249] дає 
можливість вибірково підходити до формулювання цільових критеріїв та обирати методи управління, що в найбільшій мірі відповідають умовам функціонування підприємства 3 урахуванням його масштабів та специфіки діяльності. Саме ці переваги обумовлюють те, що управління вартістю (value based management - VBM) як концепція менеджменту набуває все більшого визнання та використання не лише у розвинених країнах, але й у країнах із недостатньо розвиненими фінансовими ринками [ 250].

Сучасний етап економічного розвитку характеризується підвищенням конкуренції на національному й міжнародному рівнях а також зростанням процесів глобалізації й кластеризації, які впливають в різних напрямках на конкурентоспроможність економічних агентів. Виживання й розвиток підприємств у цих умовах залежать від багатьох факторів, серед яких в якості домінант можна виділити інноваційність і розміри цих підприємств. Сьогодні більшість зарубіжних компаній переходять до застосування вартісноорієнтованого управління, як одного 3 інноваційних і актуальних сучасних управлінських методів з метою збільшення вартості підприємства. Такий тренд набирає оберти в різних країнах і компаніях. 3 урахуванням цього доцільно включити таку ознаку в сучасний термін менеджменту, оскільки процеси інтернаціоналізації економічного розвитку мають безповоротний характер і потребують постійного збільшення розмірів компаній 3 метою вистояти в конкурентній боротьбі [ 242, с. 626].

3 іншої сторони слід ще раз підкреслити, оскільки, на наш погляд, класичний менеджмент сьогодні уже вичерпав свої можливості й він об'єктивно не може бути результативним на підприємствах, які функціонують в умовах невизначеності й кризових явищ, тому всі його функції повинні мати антикризову складову, тобто управління повинно бути перманентним антикризовим. В такому випадку і контроллінгове управління доцільно замінити на контроллінгове антикризове управління. Оскільки контроллінг має всеохоплюючий вартісно-орієнтований характер, то ця характеристика торкається й контроллінгового антикризового управління [ 240,241]. 
Таким чином, сучасний варіант контроллінгу в антикризовому управлінні підприємством може найбільш ефективно функціонувати тільки при наявності таких його монолітних компонентів як: вартісно-орієнтоване управління, контролінговий антикризовий менеджмент й динамічне управління на інноваційній основі. При цьому, мається на увазі, що контроллінг охоплює або поширюється на всі сфери діяльності й структурні підрозділи на підприємстві а антикризове управління здійснюється на постійній основі, тобто воно повністю заміняє класичний менеджмент в часі. Між цими елементами мають місце тісні зв'язки управлінського, організаційного, методичного й інструментарного характеру, а також оперативного й стратегічного напрямків. 